\title{
Pengaruh Variasi Waktu Radiasi Plasma Pijar Korona Terhadap Viabilitas, Vigor Benih, Laju Perkecambahan dan Pertumbuhan Kangkung Darat (Ipomoea reptans poir)
}

\section{Effect of Corona Incandescent Plasma Radiation Time Variations on Viability, Vigor Seeds, Germination and Growth of Water Spinach (Ipomoea reptans poir)}

\author{
Kuwati $^{1}$, Erma Prihastanti ${ }^{2 *}$ \\ ${ }^{1}$ Mahasiswa Program Studi Biologi, Departemen Biologi, Fakultas Sains dan Matemtika, \\ Universitas Diponegoro \\ ${ }^{2}$ Departemen Biologi, Fakultas Sains dan Matematika, Universitas Diponegoro \\ *Email: eprihast@yahoo.co.id
}

Diterima 27 Juli 2019 / Disetujui 30 Agustus 2019

\begin{abstract}
ABSTRAK
Permintaan sayuran semakin lama semakin meningkat. Peningkatan permintaan sayuran harus diimbangi dengan produktivitas. Kangkung darat merupakan sayuran daun yang penting di kawasan Asia. Kandungan gizi kangkung cukup tinggi terutama vitamin A dan vitamin C. Saat ini teknologi plasma dapat digunakan dalam bidang pertanian. Plasma lucutan pijar korona merupakan sumber ion, elektron, dan radikal bebas. Udara bebas mengandung banyak gas yang tidak dapat terserap langsung oleh tanaman. Radiasi plasma mampu mengionisasi gas dari udara menjadi bentuk ion yang ditembakkan dalam suatu bahan. Penelitian ini bertujuan untuk mengetahui pengaruh variasi waktu radiasi plasma terhadap viabilitas, laju perkecambahan dan laju pertumbuhan biji kangkung darat. Penelitian dilakukan di Laboratorium CPR (Center Plasma Research), Universitas Diponegoro. Rancangan penelitian yang digunakan adalah rancangan acak lengkap (RAL), dengan perlakuan perbedaan lama radiasi waktu 0, 10 menit, dan 20 menit dan pengulangan 3 kali. Parameter yang diamati viabilitas, vigor benih, dan laju perkecambahan tanaman kangkung darat. Analisis data menggunakan uji ANOVA dan uji lanjut duncan dengan taraf signifikasi 0.05. Perlakuan radiasi selama 20 menit, 10 menit dan kontrol memberikan hasil rata - rata viabilitas 87\%; 73\%; dan 53\%, laju perkecambahan 2,1 n/hari; 2,1 n/hari; dan 2,08 n/hari pada kangkung darat.
\end{abstract}

Kata kunci : radiasi, plasma pijar korona, viabilitas, vigor benih

\begin{abstract}
Demand for vegetables is increasingly increasing. The increase in vegetable demand must be balanced with the productivity of the vegetables themselves. Land kale is an important leaf vegetable in the Asian region. The nutritional content of water spinach is quite high, especially vitamin A and vitamin C. Currently to increase vegetable productivity can be done using plasma radiation technology. Corona incandescent plasma is a source of ions, electrons and free radicals. Free air contains a lot of gas that cannot be absorbed directly by plants. Plasma radiation is capable of ionizing gas from the air into an ionic form that is fired in a material. This study aims to determine the effect of variations in plasma radiation time on viability, germination rate and growth rate of land water spinach seeds. The study was conducted at the CPR Laboratory (Center Plasma Research), Diponegoro University through the RAL method. Observations carried out included viability, seed vigor, and germination rate of unripe spinach plants, terrestrial water spinach, and mustard greens after plasma radiation was carried out on seeds by control, 10 minutes and 20 minutes radiation. The results obtained were analyzed using the ANOVA test and the follow-up test with a significance level of 0.05 . Radiation treatment for 20 minutes, 10 minutes and controls gave an average viability of $87 \% ; 73 \%$; and $53 \%$, germination rate of $2.1 \mathrm{n} /$ day; $2.1 \mathrm{n} /$ day; and $2.08 \mathrm{n} /$ day on land water spinach.
\end{abstract}

Keywords: radiation, corona incandescent plasma, viability, seed vigor 


\section{PENDAHULUAN}

Kangkung darat (Ipomoea reptans) merupakan salah satu jenis sayuran yang sangat populer dan digemari oleh semua lapisan masyarakat. Hampir seluruh penduduk Indonesia $(97,29 \%)$ mengonsumsi sayur. Jenis sayuran favorit yang dikonsumsi penduduk Indonesia yaitu bayam, kangkung, kacang panjang, tomat dan terong. Rata-rata konsumsi kangkung perorang setiap minggu pada tahun 2015 yaitu 85 $\mathrm{kg}$ dan mengalami peningkatan pada tahun 2016 yaitu $92 \mathrm{~kg}$ per minggu. Perkiraan total konsumsi sayuran nasional per tahun dengan komoditi sayur kangkung pada tahun 2016 dengan jumlah penduduk 257,89 juta jiwa mengonsumsi sayur kangkung sebanyak 1232.05 juta kg (Nur dkk, 2014). Tanaman kangkung termasuk tanaman semusim, berumur pendek, dan tidak memerlukan area yang luas untuk membudidayakannya, sehingga umumnya dibudidayakan pada daerah perkotaan yang umumnya mempunyai lahan pekarangan terbatas. Kangkung mempunyai rasa yang gurih selain itu kandungan gizi pada kangkung cukup tinggi, seperti vitamin A, B, dan C serta berbagai mineral terutama zat besi yang berguna untuk pertumbuhan badan dan kesehatan (Widyastuti, dkk 2014).

Saat ini teknologi plasma telah banyak diterapkan dalam berbagai bidang diantaranya bidang pertanian, terutama dalam pengolahan makanan, benih, dan minyak. Plasma dingin dapat memberikan banyak keuntungan dalam aplikasi pertanian, seperti: dapat bekerja pada suhu yang relatif rendah, waktu pemrosesan yang relatif singkat, dan tidak meyebabkan kerusakan pada benih, tanaman pangan, makanan ternak maupun lingkungan.

Plasma dapat berpengaruh terhadap perkecambahan biji, pertumbuhan tanaman, dan kualitas produk pertanian. Perkecambahan benih dipengaruhi oleh adanya unsur nitrogen yang tersedia. Berdasarkan penelitian Fahmi (2017) Plasma pijar korona dapat mempercepat perkecambahan benih dan pertumbuhan pada tanaman sawi. Teknologi plasma dipakai sebagai pembangkit ion $\mathrm{N}^{+}$dari udara bebas. Besarnya komposisi nitrogen dalam udara bebas, hingga mencapai $80 \%$, menyebabkan peradiasian menggunakan plasma berpotensi besar menghasilkan ion $\mathrm{N}^{+}$. Selanjutnya penyusupan berkas ion nitrogen ke dalam suatu bahan akan merubah struktur mikro bahan, sehingga sifatsifat kimia dan fisika bahan tersebut juga akan ikut berubah (Nur dkk, 2014). Unsur nitrogen diperlukan semua organisme dalam hidupnya. Sebagian besar organisme hanya dapat menggunakan nitrogen dalam bentuk senayawa. Nitrogen merupakan elemen yang paling lazim ditemukan dan terdapat pada senyawa essensial tanaman seperti protein, asam nukleat, penyusun DNA, dan banyak kandungan vitamin. Disamping itu nitrogen juga digunakan dalam reaksi biokimia yang menyusun kehidupan tanaman. Tanaman dapat memperoleh unsur hara nitrogen dengan teknologi lucutan plasma dari pijar korona yang diradiasikan terhadap suatu benih tanaman. Radiasi plasma dapat digunakan untuk meningkatkan viabilitas benih, kualitas beih, dan laju perkecambahan benih.

\section{METODE PENELITIAN}

Penelitian dilaksanakan di laboratorum CPR (Center Plasma Research) departemen Fisika Universitas Diponegoro Semarang untuk peradiasian biji menggunakan plasma pijar korona, sedangkan pengamatan selama pembenihan dilaksanakan di lahan pekarangan di desa Lebeng, Kecamatan Tersono, Kabupaten Batang. Penelitian dilaksanakan dari bulan Juli sampai bulan Agustus 2017. Penelitian menggunakan rancangan acak lengkap dengan 3 perlakuan yaitu perlakuan radiasi plasma 0,10 , dan 20 menit. Bahan yang digunakan dalam penelitian ini adalah biji kangkung. Bahan pendukung lainnya diantaranya adalah air dan media tanam. Air digunakan untuk perendaman biji sebelum dikecambahkan sedangkan media tanam digunakan sebagai media pembenihan biji kangkung selama proses pengamatan. Alat yang digunakan dalam penelitian ini diantaranya adalah plasma pijar korona yang digunakan untuk 
peradiasian biji kangkung. Polybag digunakan untuk penanaman pada saat masa pengaatan.

Penyinaran plasma pijar korona dilakukan dengan tahap persiapan terlebi dahulu. Pada tahap persiapan biji kangkung di seleksi menjadi tiga kelompok sesuai dengan ukuran biji kangkung yaitu besar, sedang, dan kecil. Biji kangkung direndam di dalam air selama sebelum dilakukan penyinaran radiasi plasma untuk mengetahui kualitas biji kurang lebih selama 1015 menit. Biji kangkung yang sudah direndam dengan air kemudian ditiriskan untuk selanjutnya dilakukan penyinaran. Sebelum disinari oleh radiasi plasma biji kangkung disiapkan pada cawan petri dengan ketentuan setiap cawan petri berisi biji kangkung membentuk satu lapisan rapat. Variasi penyinaran yang dilakukan adalah penyinaran selama 10 menit dan 20 menit. Alat plasma pijar korona yang akan digunakan dibersihkan terlebih dahulu untuk menghindari adanya kontaminan. Plasma pijar korona dihidupkan dengan tegangan 4,0 volt kemudian biji kangkung dengan penyinaran 10 menit dimasukkan ke dalam plasma pijar korona dibawah tegangan 4,0 volt. Setelah penyinaran selama 10 menit biji kangkung diambil dari plasma pijar korona. Dilanjutkan dengan penyinaran biji selama 20 menit dengan tegangan yang sama yaitu 4,0 volt.

Pembenihan biji kangkung dilakukan dengan cara biji kangkung yang telah disinari dikecambahkan pada media tanam di dalam polybag yang dibagi tiga yaitu kontrol, penyinaran 10 menit dan penyinaran 20 menit. Pengamatan perkecambahan dilakukan stiap hari untuk memastikan viabilitas dan laju perkecambahan biji, dan persentase perkecambahan. Untuk menganalisis data digunakan program spss dan untuk menghitung viabilitas perkecambahannya adalah dengan cara membagi jumlah biji yang berkecambah dengan jumlah total biji yang dikecambahkan.

\section{Rumus laju perkecambahan $=$}

keterangan: (N) Jumlah benih yang berkecambah setiap hari; (T) Jumlah waktu antara awal pengujian sampai dengan akhir dari interval tertentu, untuk analisis data digunakan uji Anova pada program spss

\section{HASIL DAN PEMBAHASAN}

Penyinaran plasma 20 menit berpengaruh nyata terhadap viabilitas perkecambahan, pertambahan tinggi tanaman, dan laju perkecambahan tanaman kangkung. Berdasarkan hasil uji Anova dengan taraf signifikansi 95\% penyinaran plasma berpengaruh terhadap viabilitas perkecambahan, laju perkecambahan, dan tinggi tanaman. Perlakuan penyinaran plasma 20 menit dan 10 menit yang lebih berkualitas ditunjukkan oleh daun, batang, dan tinggi tanamannya dibandingkan dengan tanaman kangkung tanpa perlakuan (kontrol). Berdasarkan penelitian diketahui bahwa vigor benih dari biji kangkung yang paling optimal adalah pada biji kangkung yang berukuran besar. Biji kangkung yang berukuran kecil daya kecambahnya kurang dan setelah dilakukan perendaman banyak yang mengapung di air. Hasil pengamatan terhadap viabilitas perkecambahan kangkung, dari perlakuan yang diuji terhadap biji kangkung didapatkan bahwa pada perlakuan kontrol dari 15 biji yang dikecambahkan mempunyai viabilitas perkecambahan $53,3 \%$, pada perlakuan biji kangkung dengan penyinaran plasma selama 10 menit dan dari 15 biji didapatkan bahwa daya viabilitas perkecambahannya adalah $73,3 \%$, pada perlakuan biji kangkung dengan penyinaran plasma selama 20 menit daya viabilitas perkecambahannya adalah $86,6 \%$.

Perkecambahan benih kangkung dengan perlakuan kontrol (tanpa penyinaran) dan penyinaran plasma pada biji kangkung selama 10 menit tidak mencapai daya viabilitas yang baik, dikarenakan presentasenya kurang dari $80 \%$, sedangkan penyinaran plasma selama 20 menit daya viabilitasnya mencapai lebih dari $80 \%$ yaitu $87 \%$. Viabilitas perkecambahan benih kangkung yang paling optimal adalah pada penyinaran plasma selama 20 menit. Radiasi plasma pada 
benih kangkung dengan durasi waktu yang tepat meningkatkan ion nitrogen yang terdifusi kedalam benih. Ion nitrogen tersebut diduga disimpan didalam benih sebagai persediaan untuk pertumbuhan selanjutnya. Semakin lama durasi penyinaran maka nitrogen yang ditembakkan semakin banyak. Proses pertumbuhan tanaman kangkung darat dimulai dari pematahan dormansi benih yang menyebabkan benih berkecambah. Menurut Agurahe dkk (2019) perkecambahan dimulai dengan imbibisi air kedalam benih yang memacu enzim-enzim metabolisme.

Tabel 1. Perkecambahan tanaman kangkung darat (Ipomoea reptans poir) pada radiasi plasma 0, 10, dan 20 menit.

\begin{tabular}{ccccccccc}
\hline \multirow{2}{*}{ Perlakuan } & Ukuran & \multicolumn{7}{c}{ Perkecambahan (cm) } \\
\cline { 3 - 9 } & & 1 Hst & 2 Hst & 3 Hst & 4 Hst & 5 Hst & 6 Hst & 7 Hst \\
\hline Kontrol & Besar & 0 & 3 & 3 & 3 & 3 & 3 & 3 \\
& Sedang & 0 & 3 & 3 & 3 & 3 & 3 & 3 \\
& Kecil & 0 & 1 & 2 & 2 & 2 & 2 & 2 \\
Penyinaran 10 & Besar & 0 & 4 & 4 & 4 & 4 & 4 & 4 \\
menit & Sedang & 0 & 4 & 4 & 4 & 4 & 4 & 4 \\
& Kecil & 0 & 3 & 3 & 3 & 3 & 3 & 3 \\
Penyinaran 20 & Besar & 0 & 5 & 5 & 5 & 5 & 5 & 5 \\
menit & Sedang & 0 & 5 & 5 & 5 & 5 & 5 & 5 \\
& Kecil & 0 & 3 & 3 & 3 & 3 & 3 & 3 \\
\hline
\end{tabular}

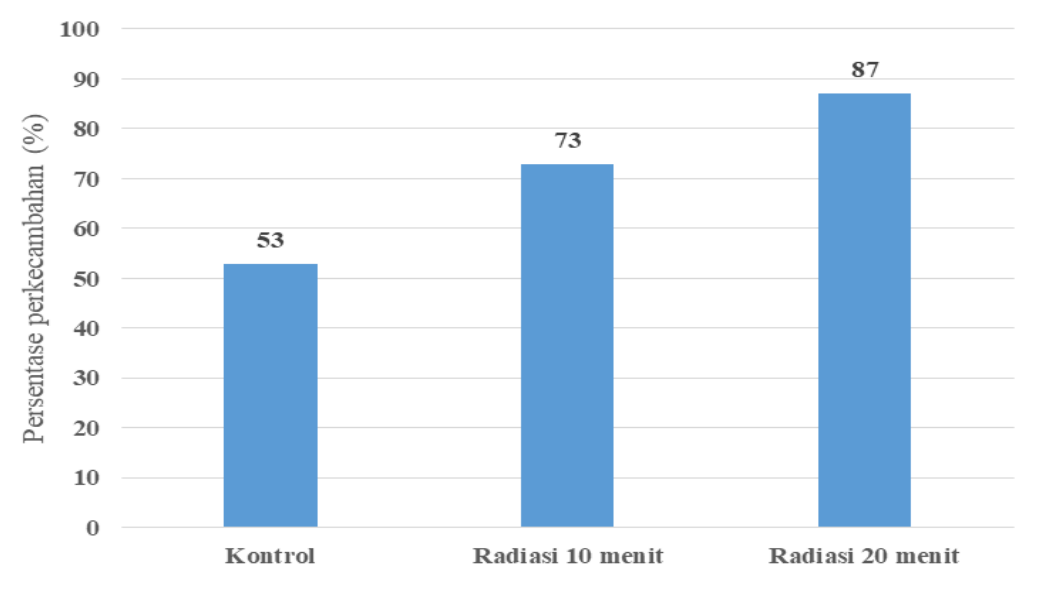

Gambar 1. Persentase Perkecambahan Tanaman Kangkung darat (Ipomoea reptans $\mathrm{P}$.

Perkecambahan benih dipengaruhi oleh 2 faktor yaitu dari faktor dalam (tingkat kemasakan benih, ukuran benih, dormansi) dan faktor luar (air, temperatur, oksigen dan cahaya). Berdasarkan penelitian Nur (2007) Pendeposisian ion dan radikal bebas nitrogen yang dihasilkan oleh plasma lucutan pijar korona pada organ daun tanaman anggrek Phalaenopsis amabilis secara fisik tidak merusak organ tumbuhan yang diradiasi atau organ lain pada tanaman. Kerusakan tanaman seperti rontok atau layunya daun, rontok atau berkerutnya akar bukan merupakan akibat dari pemberian plasma melainkan karena kondisi lingkungan yang kurang cocok. Akar atau daun anggrek dapat berkerut atau membusuk akibat suhu, kelembaban atau tempat tumbuh yang kurang sesuai.

Kecepatan berkecambah adalah kecepatan benih untuk berkecambah, dapat dihitung dengan menghitung jumlah hari yang diperlukan untuk munculnya radikula dan plumulae ${ }^{[8]}$. Berdasarkan tabel 3 diketahui bahwa laju kecepatan perkecambahan pada perlakuan 
penyinaran plasma selama 10 menit dan 20 menit memiliki nilai rata-rata yang sama yaitu 2,1/hari, sedangkan laju perkecambahan pada biji kangkung tanpa perlakuan (kontrol) adalah 2,08/hari. Hasil uji anova dengan taraf kepercayaan $95 \%$ menunjukkan perlakuan penyinaran radiasi plasma dan kontrol berbeda nyata. Hal ini disebabkan karena sebelum penanaman biji kangkung sudah mendapatkan unsure nitrogen yang ditembakkan kedalam biji, sehingga biji sudah menyerap unsur $\mathrm{N}$ pada waktu diradiasi. Perkecambahan dipengaruhi oleh hormon giberelin yang diaktifkan karena proses imbibisi. Sedangkan, nitrogen menghasilkan asam amino yang menghasilkan triptofan dan menghasilkan auksin (IAA) dan sitokinin yang digunakan untuk pertumbuhan selanjutnya.

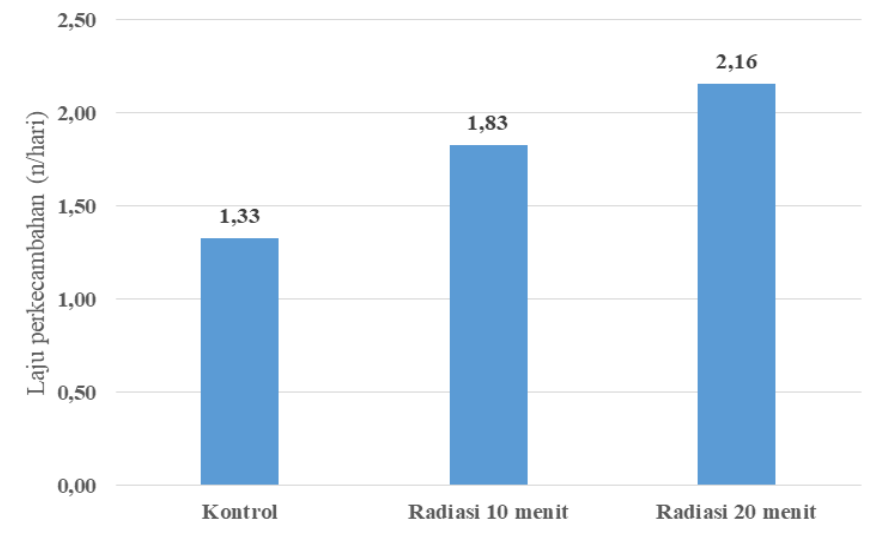

Gambar 2. Laju perkecambahan kangkung darat (Ipomoea reptans P.)

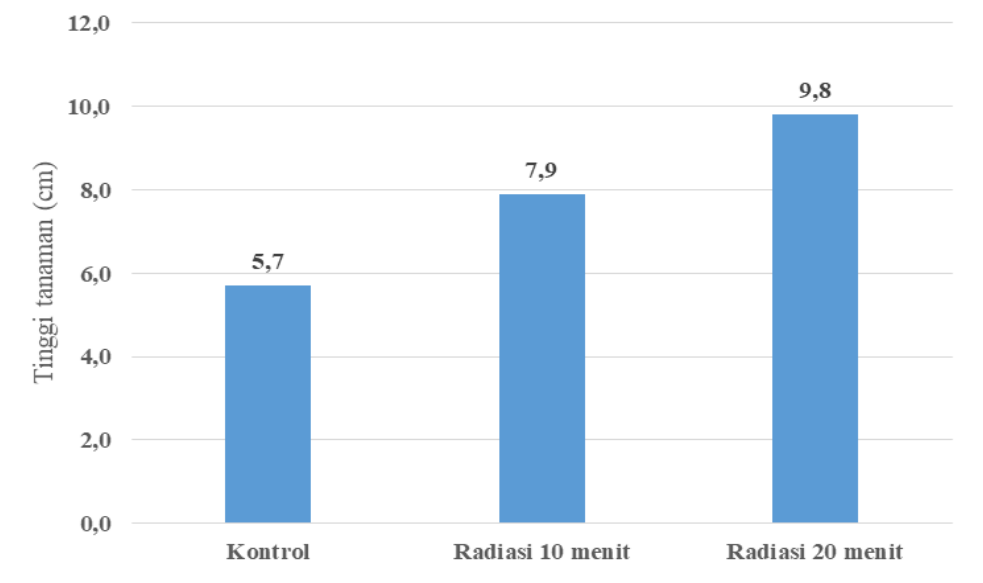

Gambar 3. Tinggi tanaman kangkung darat (Ipomoea reptans P.)

Hasil penelitian menunjukkan rerata tinggi tanaman yang diradiasi plasma selama 20 menit berbeda nyata terhadap kontrol dan radiasi plasma selama 10 menit. Sedangkan penyinaran radiasi plasma selama 10 menit tidak memberikan perbedaan yang signifikan dengan tanaman kangkung kontrol (tanpa radiasi). Berdasarkan penelitian menunjukkan bahwa penggunaan radiasi ion nitrogen dari plasma meningkatkan pertumbuhan tanaman. Menurut
Nur et al (2014), Lucutan plasma pijar korona dapat menghasilkan ion nitrogen dari udara bebas yang mengandung $78 \%$ molekul nitrogen. Ketika dibangkitkan plasma pada udara bebas maka molekul nitrogen akan terionisasi atau terbentuk radikal bebas. Ion-ion $\mathrm{N} 2+$ inilah yang diemplementasikan ke tanaman sehingga terjadi penambahan unsur hara secara efektif dan akhirnya akan mempercepat laju pertumbuhan $\operatorname{tanaman}^{[6]}$. Menurut Leveau dan Lindow (2005) 
pemberian nitrogen akan meningkatkan asam amino antara lain triptofan yang merupakan prekursor auksin berupa IAA (Indol Acetic Acid) dalam tanaman yang berfungsi mengendalikan proses fisiologi seperti pembelahan dan pembesaran sel maupun diferensiasi jaringan. Menurut Apriliani dkk (2015) auksin memiliki peran penting dalam mempercepat pertumbuhan, baik pertumbuhan akar maupun pertumbuhan batang, mempercepat perkecambahan, serta membantu dalam proses pembelahan sel. Unsur $\mathrm{N}$ berfungsi sebagai sebagai pembentuk klorofil dan berperan penting dalam fotosintesis (Adil dkk, 2005; Pramitasari dkk, 2015). Jika N meningkat maka klorofil juga meningkat, sehingga fotosintat yang dihasilkan juga banyak diakumulasikan ke pertumbuhan tinggi tanaman serta merangsang pertumbuhan.

\section{KESIMPULAN}

Penyinaran radiasi plasma pijar korona berpengaruh terhadap perkecambahan benih pada biji kangkung darat (Ipomoea reptans poir) diantara 3 perlakuan yang telah dilakukan yaitu kontrol, penyinaran 10 menit, dan penyinaran 20 menit yang paling optimal pada perkecambahan biji kangkung adalah penyinaran plasma selama 20 menit yaitu dengan viabilitas perkecambahan, laju perkecambahan, dan tinggi tanaman.

\section{DAFTAR PUSTAKA}

Agurahe, Lisa., Rampe, Henny L., dan Mantiri, Feky R.2019. Pematahan Dormansi Benih Pala (Myristica Fragrans Houtt.) Menggunakan Hormon Giberalin. Jurnal Ilmiah Farmasi 8 (1) : 30 - 40

Fahmi, R. U. (2017). Corona Discharge Multipoint Plane Configuration ad its Application For Growth Acceleration of Mug Bean Plants. Teknologi Plasma, 19.

Leveau, J.H.J. \& S.E. Lindow. 2005. Utilization of The Plant Hormone Indole-3-Acet Acid for Growth by Psedomonas putida Strain 1290. Applied and Environmental Microbiology. 71 (5): 2365-2371
Nur, M., N. J. (2013). Penerapan Teknologi Plasma Untuk Mempercepat Persemaian Mangrove Sebagai Upaya Rehabilitasi Green Belt Untuk mengatasi Abrasi. Riptek , Vol.7, No.1. Hal 15-26.

Nur,M.,A.H,Azzulkha,M.Restiwijaya,Z.Muchlisi $\mathrm{n}$ and Sumariyah.2014.The Study of Electro Hydrodynamic and Wind Ions Direction Produced by Positive Corona Plasma Discharge.IISTE.Vol.30:55-64.

Nur,M.Pandji,T,Nasrudin.2007.Rancang Bangun dan Pengujian Sistem Reaktor Plasma Lucutan Pijar Korona Guna Mempercepat Pertumbuhan Tanaman Mangrove.Berkala Fisika.Vol.10.No.3.

Payung,D.,Eva,P. dan Syafaatul.H.N.2012.Uji Daya Kecambah Benih Sengon (Parasesianthes Falcataria L Nielsen.) di Green House.Jurnal Hutan Tropis.Vol.13.No.2:132-138.

Pramitasari, Harin Eki., Wardiyati, Tatik., dan Nawawi, Mochammad. 2015. Pengaruh Dosis Pupuk Nitrogen dan Tingkat Kepadatan Tanaman Terhadap Pertumbuhan dan Hasil Tanaman Kailan (Brassica oleraceae L.). Jurnal Produksi Tanaman 4 (1) : $49-56$

Syafitri, E. (2014). Pengaruh Pemberian Pupuk Organik Teradap Pertumbuhandan Hasil Tanaman Kangkung Darat (Ipomoea reptans poir). Balai Pengkajian Teknologi Pertanian (BPTP), Vol 3, No.1.

Widyastuti, W., Mardiati, S. M. \& Saraswati, T. R., 2014. Pertumbuhan Puyuh (Coturnix coturnix japonica) Setelah Pemberian Tepung Kunyit (Curcuma longa L.) Pada Pakan. Buletin Anatomi dan Fisiologi, XXII(2), pp. 12-20. 